\title{
Activities of principal photosynthetic enzymes in green macroalga Ulva linza: functional implication of $\mathrm{C}_{4}$ pathway in $\mathrm{CO}_{2}$ assimilation
}

\author{
XU JianFang ${ }^{1}$, ZHANG XiaoWen ${ }^{2}$, YE NaiHao ${ }^{2 *}$, ZHENG Zhou $^{1}$, MOU ShanLi $^{2}$, \\ DONG MeiTao ${ }^{3}$, XU Dong ${ }^{2} \&$ MIAO JinLai ${ }^{*}$ \\ ${ }^{1}$ Key Laboratory of Marine Bioactive Substance, The First Institute of Oceanography, State Oceanic Administration, Qingdao 266061, China; \\ ${ }^{2}$ Yellow Sea Fisheries Research Institute, Chinese Academy of Fishery Sciences, Qingdao 266071, China; \\ ${ }^{3}$ Qingdao Agricultural University, Qingdao 266109, China
}

Received September 18, 2012; accepted April 19, 2013

\begin{abstract}
The green-tide-forming macroalga Ulva linza was profiled by transcriptome sequencing to ascertain whether the alga carries both $\mathrm{C}_{3}$ and $\mathrm{C}_{4}$ photosynthesis genes. The key enzymes involved in $\mathrm{C}_{4}$ metabolism including pyruvate orthophosphate dikinase (PPDK), phosphoenolpyruvate carboxylase (PEPC), and phosphoenolpyruvate carboxykinase (PCK) were found. When measured under normal and different stress conditions, expression of $r b c \mathrm{~L}$ was higher under normal conditions and lower under the adverse conditions, whereas that of PPDK was higher under some adverse conditions, namely desiccation, high salinity, and low salinity. Both ribulose-1, 5-biphosphate carboxylase (RuBPCase) and PPDK were found to play a role in carbon fixation, with significantly higher PPDK activity across the stress conditions. These results suggest that elevated PPDK activity alters carbon metabolism in $U$. linza leading to partial operation of the $\mathrm{C}_{4}$ carbon metabolism, a pathway that, under stress conditions, probably contributes to the hardy character of $U$. linza and thus to its wide distribution.
\end{abstract}

$\mathrm{C}_{4}$ pathway, PPDK, RuBPCase, Ulva linza

Citation: $\quad \mathrm{Xu} \mathrm{J} \mathrm{F,} \mathrm{Zhang} \mathrm{X} \mathrm{W,} \mathrm{Ye} \mathrm{N} \mathrm{H,} \mathrm{et} \mathrm{al.} \mathrm{Activities} \mathrm{of} \mathrm{principal} \mathrm{photosynthetic} \mathrm{enzymes} \mathrm{in} \mathrm{green} \mathrm{macroalga} \mathrm{Ulva} \mathrm{linza:} \mathrm{functional} \mathrm{implication} \mathrm{of} \mathrm{C}_{4}$ pathway in $\mathrm{CO}_{2}$ assimilation. Sci China Life Sci, 2013, 56: 571-580, doi: 10.1007/s11427-013-4489-x

Plants can be classified into three major categories $-\mathrm{C}_{3}$ plants, $\mathrm{C}_{4}$ plants, and Crassulacean acid metabolism (CAM) plants - based on the mechanism by which they assimilate carbon during photosynthesis. The most common and the most primitive of the three photosynthetic pathways is the $\mathrm{C}_{3}$ pathway, which is characterized by an initial $\mathrm{CO}_{2}$ carboxylation to form a 3-carbon acid, namely phosphoglyceric acid (PGA) [1]. However, atmospheric $\mathrm{CO}_{2}$ is first incorporated into $\mathrm{C}_{4}$ acids in $\mathrm{C}_{4}$ pathway. The $\mathrm{C}_{4}$ pathway is a complex trait that has evolved from ancestral $\mathrm{C}_{3}$ plants via a series of anatomical and physiological adaptations [2,3].

*Corresponding author (email: yenh@ysfri.ac.cn; miaojinlai@163.com)
Compared with $\mathrm{C}_{3}$ plants, $\mathrm{C}_{4}$ plants utilize a biochemical $\mathrm{CO}_{2}$-concentrating mechanism combining a faster rubisco that make them to use nitrogen and water more effectively [4]. $\mathrm{C}_{3}-\mathrm{C}_{4}$ intermediates which possess the characteristics of both $\mathrm{C}_{3}$ plants and $\mathrm{C}_{4}$ plants, may be a transitional stage in the evolution of $\mathrm{C}_{4}$ pathway from $\mathrm{C}_{3}$ pathway [5].

The mechanisms of uptake and fixation of inorganic carbon $(\mathrm{Ci})$ have been researched extensively in land plants whereas information on the photosynthetic pathway in aquatic plants is relatively scarce, and no fixed standard is so far available for classifying them on the basis of their photosynthesis pathway. Aquatic higher plants, such as some species of Hydrilla, Egeria, Orcuttia, and Eleocharis, 
can utilize a $\mathrm{C}_{4}$ photosynthetic system that surprisingly lacks the Kranz dual-cell compartmentation found in most terrestrial $\mathrm{C}_{4}$ plants [6]. Under some forms of stress, malate decarboxylation by NADP malic enzyme (NADP-ME) in the chloroplasts of such facultative $\mathrm{C}_{4}$ species triggers a chloroplastic $\mathrm{CO}_{2}$ concentrating mechanism (CCM) [6]. Both $\mathrm{C}_{4}$ and $\mathrm{C}_{3}$ cycles operate in the same cell, with phosphoenolpyruvate carboxylase (PEPC) and ribulose bisphosphate carboxylase-oxygenase (rubisco) being sequestered in the cytosol and chloroplasts respectively [6]. Hydrilla verticillata, an aquatic plant which typically exhibits $\mathrm{C}_{3}$ gas-exchange and biochemical characteristics, can be induced to be a $\mathrm{C}_{4}$-based $\mathrm{CCM}$ under exposure to low $\mathrm{CO}_{2}$ within 10-12 days [7]. The change from $C_{3}$ to $C_{4}$ can occur without the production of new leaves, and has been documented in situ (in lakes) as well as the laboratory [7,8]. Under low $\mathrm{CO}_{2}$ concentration, $\mathrm{C}_{4}$ pathway genes are upregulated and expressed in the original $\mathrm{C}_{3}$ mesophyll cell $[7,9]$.

Marine algae, despite $\mathrm{CO}_{2}$-limiting conditions in the oceans [10], manage to increase the steady-state $\mathrm{CO}_{2}$ concentration around rubisco, the principal photosynthetic carboxylase, by actively using CCM [11-13]. This mechanism diminishes the wasteful process of photorespiration by increasing the ratio of $\mathrm{CO}_{2}$ to $\mathrm{O}_{2}$. Despite its great ecological impact, photosynthetic carbon acquisition by marine algae is only poorly understood so far. Photosynthetic carbon fixation pathways of marine macroalgae generally follow the $\mathrm{C}_{3}$ pathway [14], however, recent metabolic labeling and genome sequencing data suggest that the algae also use the $\mathrm{C}_{4}$ pathway, and the marine diatom Thalassiosira weissflogii has been reported to do so in a single cell $[15,16]$. The relevant genes involved in $\mathrm{C}_{4}$ photosynthesis were also observed in the diatom Phaeodactylum tricornutum [17] and the green alga Ostreococcus tauri [18]. PEPC activity in $T$. weissflogii increases in cells acclimatized to low $\mathrm{CO}_{2}$, indicating a probable link between inorganic carbon uptake and PEPC [15]. McGinn and Morel (2008) also observed two PEPC gene transcripts in T. pseudonana cells up-regulated 2- to 4-fold in order to acclimatized to low $\mathrm{CO}_{2}$ [19]. When the activity of PEPCase was restrained by 3,3-dichloro-2dihydroxyphosphinoylmethyl-2-propenoate in $T$. weissflogii cells adapted to low $\mathrm{CO}_{2}\left(10 \mu \mathrm{mol} \mathrm{L} \mathrm{L}^{-1}\right)$, the whole cell photosynthesis decreased by more than $90 \%$, but had little influence on photosynthesis in the $\mathrm{C}_{3}$ algae Chlamydomonas sp. [16].

The genus Ulva is believed to behave as a typical $\mathrm{C}_{3}$ plant at the biochemical level [20]. Ulva linza, the dominant Ulva species along the coastline of the Yellow Sea before May [21], is a representative green-tide-forming macroalga [22]. Being an intertidal species, $U$. linza must face and cope with extremes of temperature, solar radiation, and desiccation by means of high physiological efficiency and molecular adjustment [23,24]. Moreover, evolution places intertidal multicellular green algae between unicellular green algae and lower land plants; the organisms represent an important link in the evolution [25] and are therefore particularly valuable in investigating the evolution of the $\mathrm{CO}_{2}$ fixation pathway. The present study, by transcriptomic sequence and analysis, first confirmed the coexistence of genes necessary for $\mathrm{C}_{3}$ and $\mathrm{C}_{4}$ pathway in $U$. linza and subsequently focused on two key enzymes, namely RuBPCase and PPDK. Ribulose-1,5-biphosphate carboxylase, a key enzyme of the $\mathrm{C}_{3}$ pathway, is widely distributed in photosynthetic organisms and catalyzes the photosynthetic fixation of $\mathrm{CO}_{2}$ through the Calvin cycle. Pyruvate orthophosphate dikinase, a key enzyme of the $\mathrm{C}_{4}$ pathway, catalyzes the formation of phosphoenolpyruvate (PEP), the initial acceptor of $\mathrm{CO}_{2}$ in the $\mathrm{C}_{4}$ pathway [26]. The formation of PEP by PPDK is considered to be the rate-limiting step for the lowest reaction rate in the $\mathrm{C}_{4}$ pathway [27,28]. Our results lead us to believe that $U$. linza may perform $\mathrm{C}_{4}$ photosynthetic pathway and contribute to the large-scale bloom of U. linza.

\section{Materials and methods}

\subsection{Sampling and culture conditions}

Samples of $U$. linza were collected in April 2011 from the intertidal zone $\left(35^{\circ} 35^{\prime} \mathrm{N}, 119^{\circ} 30^{\prime} \mathrm{E}\right)$ of Zhanqiao Wharf, Qingdao, China. In the laboratory, the intact samples were washed several times with sterile seawater, sterilized with $1 \%$ sodium hypochlorite for $2 \mathrm{~min}$, and then rinsed with autoclaved seawater. The sterilized material was then placed into an aquarium containing enriched and continually aerated seawater $\left(500 \mu \mathrm{mol} \mathrm{L} \mathrm{L}^{-1} \mathrm{NaNO}_{3}\right.$ and $50 \mu \mathrm{mol} \mathrm{L} \mathrm{L}^{-1}$ $\mathrm{NaH}_{2} \mathrm{PO}_{4}$ ) and maintained at $10^{\circ} \mathrm{C}$ under a cycle comprising $12 \mathrm{~h}$ of light alternating with $12 \mathrm{~h}$ of darkness. The light intensity was $50 \mu \mathrm{mol} \mathrm{m} \mathrm{m}^{-2} \mathrm{~s}^{-1}$ provided by cool-white fluorescent tubes [28].

\subsection{Transcriptome sequencing}

$U$. linza were exposed under low temperature $\left(5^{\circ} \mathrm{C}\right)$ and high temperature $\left(42^{\circ} \mathrm{C}\right)$ for $1 \mathrm{~h}$, respectively. The samples were placed under high light intensity $\left(1000 \mu \mathrm{mol} \mathrm{m}^{-2} \mathrm{~s}^{-1}\right)$, high salinity (93\%o) and UV-B radiation $\left(60 \mu \mathrm{W} \mathrm{cm}{ }^{-2}\right)$ for 3 $\mathrm{h}$, respectively. Total RNA from every treated sample was extracted and purified, followed by synthesis and purification of double-stranded cDNA and sequencing of cDNA using a Roche GS FLX Titanium platform. To reconstruct the metabolic pathways in $U$. linza, high-quality reads were assigned to the Kyoto Encyclopedia of Genes and Genomes (KEGG) using the software package MEGAN (version 4.0) [29].

\subsection{Sequence analysis}

The cDNA open reading frame $(\mathrm{ORF})$ sequence of $r b c \mathrm{~L}$, 
acquired from GenBank, and of PPDK, obtained by transcriptome sequencing, were examined for homology with other known sequences using the BLAST X program available at the website of the National Center for Biotechnology Information (www.ncbi.nlm.nih.gov/blast). The deduced amino acid sequence was analyzed with the Six Frame Translation of Sequence system (http://molbiol.ru/eng/ scripts/01_13.html). At last, the $r b c \mathrm{~L}$ cDNA sequence (DQ813497) of ORF was acquired from GenBank with a 1425 bp sequence, which encodes 474 amino acid residues. The PPDK cDNA sequence (JN222388) of ORF was obtained from the $U$. linza transcriptome database with a $2700 \mathrm{bp}$ sequence encoding 889 amino acid residues.

\subsection{Chlorophyll fluorescence measurements}

Fluorescence of PS II of $U$. linza was determined in vivo by pulse amplitude modulation using Dual-PAM-100 (Walz $\mathrm{GmbH}$, Germany). The minimum fluorescence yield $\left(F_{0}\right)$ was determined using 15 min dark-adapted samples and the maximum fluorescence yield $\left(F_{\mathrm{m}}\right)$ obtained by applying saturating pulses [30].

The following formulae were used to calculate the optimum quantum yield $\left(F_{\mathrm{v}} / F_{\mathrm{m}}\right)$ and the effective PS II quantum yield $(Y(\mathrm{II}))$, which reflect the potential and the actual rate of photosynthesis, respectively [31]:

$$
\begin{gathered}
F_{\mathrm{v}} / F_{\mathrm{m}}=\left(F_{\mathrm{m}}-F_{0}\right) / F_{\mathrm{m}}, \\
Y(\mathrm{II})=\left(F^{\prime}{ }_{\mathrm{m}}-F\right) / F^{\prime}{ }_{\mathrm{m}},
\end{gathered}
$$

where $F^{\prime}$ m represents the maximum fluorescence yield from light-adapted samples. $F$ is the fluorescence yield from light-adapted samples.

All the results in this study were expressed as mean values, and these were used for statistical analysis (ANOVA) using SPSS (version 17.0).

\subsection{Stress treatments}

The alga was subjected to different kinds of stress, namely desiccation and differing levels of salinity, light intensity, and temperature. Desiccation stress took the form of exposure to $50 \mu \mathrm{mol}$ photons $\mathrm{m}^{-2} \mathrm{~s}^{-1}$ for different durations $(0,1$, $2,3,4$, and $5 \mathrm{~h}$ ); salinity stress consisted of subjecting the organism for $1 \mathrm{~h}$ to different salt concentrations $(0 \%, 15 \%$, $30 \%$, 45\%o, and 60\%o); and light intensity treatment consisted of $1 \mathrm{~h}$ exposure to 0, 50, 200, 600, 1000, and 2000 $\mu \mathrm{mol} \mathrm{m} \mathrm{s}^{-2}$. For the three forms of stress, temperature was constant at $10^{\circ} \mathrm{C}$, and light intensity during the salinity treatment and the temperature treatment was maintained at $50 \mu$ mol photons $\mathrm{m}^{-2} \mathrm{~s}^{-1}$. Temperature stress involved exposure for $1 \mathrm{~h}$ to $0,5,10,15,20,25$, and $30^{\circ} \mathrm{C}$. Following each stress treatment, $F_{\mathrm{v}} / F_{\mathrm{m}}$ and $Y(\mathrm{II})$ was measured by Dual-PAM-100, $r b c \mathrm{~L}$ and $P P D K$ mRNA expression level determined using qPCR, and RuBPCase and PPDK activity assessed.

\subsection{Real-time quantitative PCR}

Total RNA of $U$. linza samples exposed to each form and level of stress was extracted using TRIzol reagent (Invitrogen, Carlsbad, CA, USA) as specified in the user manual and dissolved in diethypyrocarbonate (DEPC)-treated water. The cDNA used for real-time quantitative PCR was synthesized from the total RNA using Moloney murine leukemia virus reverse transcriptase (Promega Biotech Co., Madison, Wisconsin, USA).

The real-time quantitative PCR reactions were performed with the ABI StepOne Plus Real-Time PCR System (Applied Biosystems, USA) using SYBR Green fluorescence (TaKaRa) according to the manufacturer's instructions. To normalize the relative expression of the selected genes, an 18S rDNA gene was used as reference [32]. Three pairs of gene-specific primers (Table 1) were designed according to the $r b c \mathrm{~L}$ cDNA, PPDK cDNA, and $18 \mathrm{~S}$ rDNA sequences using Primer Express 3.0. For each selected gene, three biological replicates were assayed independently. The qPCR amplifications were carried out in a total volume of $20 \mu \mathrm{L}$ containing $10 \mu \mathrm{L}$ of $2 \times$ SYBR Premix Ex TaqTM II (TaKaRa Biotech Co., Dalian, China), $0.6 \mu \mathrm{L}\left(10 \mu \mathrm{mol} \mathrm{L}{ }^{-1}\right)$ of each primer, $2.0 \mu \mathrm{L}$ of the diluted cDNA mix, and $6.8 \mu \mathrm{L}$ de-ionized water. The qPCR amplification profile was obtained as follows: $95^{\circ} \mathrm{C}$ for $30 \mathrm{~s}$ followed by 40 cycles of $95^{\circ} \mathrm{C}$ for $5 \mathrm{~s}, 60^{\circ} \mathrm{C}$ for $10 \mathrm{~s}$, and $72^{\circ} \mathrm{C}$ for $40 \mathrm{~s}$. The $2^{-\Delta \Delta C_{\mathrm{T}}}$ method was used to analyze the quantitative real-time PCR data.

\subsection{Enzyme assays}

The activity of RuBP carboxylase and PPDK in samples exposed to the treatments was measured, RuBP carboxylase activity by the method described by Gerard and Driscoll (1996) and PPDK activity by that described by Sayre, Kennedy and Pringnitz (1979) [33,34]; both methods were modified as required.

For measuring RuBP carboxylase activity, each sample was ground to a fine powder in liquid nitrogen and homogenized in pre-cooled rubisco extraction solution $\left(1 \mathrm{~mL} \mathrm{~g}^{-1}\right.$ fresh weight), $\mathrm{pH} 7.6$, containing $40 \mathrm{mmol} \mathrm{L}^{-1}$ Tris- $\mathrm{HCl}$ buffer with $10 \mathrm{mmol} \mathrm{L}^{-1} \mathrm{MgCl}_{2}, 0.25 \mathrm{mmol} \mathrm{L}^{-1}$ EDTA, and $5 \mathrm{mmol} \mathrm{L}{ }^{-1}$ reduced glutathione. The homogenate was centrifuged at $10000 \times g$ for $10 \mathrm{~min}$ at $4^{\circ} \mathrm{C}$. The activity was

Table 1 Primers used in the qPCR assay

\begin{tabular}{cll}
\hline Name & & \multicolumn{1}{c}{ Primer sequence $\left(5^{\prime}-3^{\prime}\right)$} \\
\hline \multirow{2}{*}{$r b c \mathrm{~L}$} & $\mathrm{~F}$ & TACAAATCTCAAGCCGAAACTG \\
& $\mathrm{R}$ & AATCTTTAGCAAATTGACCACG \\
\hline \multirow{2}{*}{ PPDK } & $\mathrm{F}$ & CACGAACGACCTTACGCAGA \\
& $\mathrm{R}$ & ACGGATCAAACGCCATCAC \\
\hline \multirow{2}{*}{$18 \mathrm{~S}$ rDNA } & $\mathrm{F}$ & ATTAGATACCGTCGTAGTCTCAACC \\
& $\mathrm{R}$ & TCTGTCAATCCTTCCTATGTCTGG \\
\hline
\end{tabular}


measured in a $4.5 \mathrm{~mL}$ cuvette by adding $3 \mathrm{~mL}$ of a reaction mixture containing $0.2 \mathrm{~mL}$ NADH $\left(5 \mathrm{mmol} \mathrm{L}{ }^{-1}\right), 0.2 \mathrm{~mL}$ ATP $\left(50 \mathrm{mmol} \mathrm{L}^{-1}\right), 0.1 \mathrm{~mL}$ enzyme extract, $0.2 \mathrm{~mL}$ creatine phosphate $\left(50 \mathrm{mmol} \mathrm{L}^{-1}\right), 0.2 \mathrm{~mL} \mathrm{NaHCO}_{3}(0.2 \mathrm{mmol}$ $\left.\mathrm{L}^{-1}\right), 1.4 \mathrm{~mL}$ reaction buffer $\left(0.1 \mathrm{~mol} \mathrm{~L}^{-1}\right.$ Tris- $\mathrm{HCl}$ buffer, pH 7.8, with $12 \mathrm{mmol} \mathrm{L}^{-1} \mathrm{MgCl}_{2}$ and $0.4 \mathrm{mmol} \mathrm{L}^{-1}$ EDTA), $0.1 \mathrm{~mL}$ creatinephosphokinase $\left(160\right.$ units $\left.\mathrm{mL}^{-1}\right), 0.1 \mathrm{~mL}$ phosphoglycerate kinase $\left(160\right.$ units $\left.\mathrm{mL}^{-1}\right), 0.1 \mathrm{~mL}$ glyceraldehyde-3-phosphate dehydrogenase $\left(160\right.$ units $\left.\mathrm{mL}^{-1}\right)$, and $0.3 \mathrm{~mL}$ distilled water. The reaction was initiated by adding $0.1 \mathrm{~mL}$ ribulose-1, 5-bisphosphate (RuBP) to the reaction cuvette and $A$ values were recorded every $20 \mathrm{~s}$ for $3 \mathrm{~min}$ by a spectrophotometer at $340 \mathrm{~nm}$. The enzyme activity was expressed in terms of micromoles per gram of fresh weight per minute $\left(\mu \mathrm{mol} \mathrm{g}^{-1} \mathrm{FW} \mathrm{min}^{-1}\right)$.

For measuring PPDK activity, the samples were ground to a fine powder in liquid nitrogen and homogenized in pre-cooled PPDK extraction solution at $\mathrm{pH} 8.3\left(1 \mathrm{~mL} \mathrm{~g}^{-1}\right.$ fresh weight) containing $100 \mathrm{mmol} \mathrm{L}^{-1}$ Tris- $\mathrm{HCl}$ buffer with $5 \mathrm{mmol} \mathrm{L}^{-1}$ mercaptoethanol and $2 \mathrm{mmol} \mathrm{L}{ }^{-1}$ EDTA. The homogenate was centrifuged at $10000 \times g$ for $10 \mathrm{~min}$ at $4^{\circ} \mathrm{C}$. The activity was measured in a $4.5 \mathrm{~mL}$ cuvette by adding $3 \mathrm{~mL}$ of a reaction mixture containing $0.1 \mathrm{~mL}$ Tris-HCl buffer $\left(150 \mathrm{mmol} \mathrm{L}^{-1}, \mathrm{pH} 8.3\right.$, with $18 \mathrm{mmol} \mathrm{L}^{-1}$ $\left.\mathrm{MgSO}_{4}\right), 0.1 \mathrm{~mL}$ DTT $\left(300 \mathrm{mmol} \mathrm{L}^{-1}\right), 0.1 \mathrm{~mL}$ PEP (30 mmol L $\left.{ }^{-1}\right), 0.1 \mathrm{~mL}$ NADH $\left(4.5 \mathrm{mmol} \mathrm{L}^{-1}\right), 0.1 \mathrm{~mL}$ AMP $\left(30 \mathrm{mmol} \mathrm{L}^{-1}\right), 0.1 \mathrm{~mL}$ lactic dehydrogenase (60 units
$\mathrm{mL}^{-1}$ ), $0.1 \mathrm{~mL}$ enzyme extract, and $1.3 \mathrm{~mL}$ distilled water. The reaction was initiated by adding $0.1 \mathrm{~mL}$ pyrophosphate natrium to the reaction cuvette and the $A$ values were recorded every $20 \mathrm{~s}$ for $3 \mathrm{~min}$ at $340 \mathrm{~nm}$. The PPDK activity was also expressed in terms of micromoles per gram of fresh weight per minute $\left(\mu \mathrm{mol} \mathrm{g}^{-1} \mathrm{FW} \mathrm{min}^{-1}\right)$.

\section{Results}

\subsection{Transcriptome sequencing}

To uncover the genomic mechanisms of $U$. linza when exposed to different forms of stress, a mixed transcriptome were sequenced by using Roche GS FLX Titanium as a platform to uncover the genomic mechanisms underlying rapid and successful colonization. A total of 503789 raw reads with an average length of $396 \mathrm{bp}$ were generated by transcriptome sequencing, and 382884 reads were assembled into 13426 contigs with an average length of 1000 bases. KEGG analysis showed that 9356 reads were assigned to the carbon fixation pathway, which encode key genes of such enzymes as phosphoenolpyruvate carboxylase, aspartate aminotransferase, ribulose bisphosphate carboxylase, phosphoglycerate kinase, phosphoribulokinase, phosphoenolpyruvate carboxykinase, alanine transaminase, malate dehydrogenase (NADP+), pyruvate orthophosphate dikinase, and pyruvate kinase. This suggests the coexistence of the Calvin cycle $\left(\mathrm{C}_{3}\right)$ and Hatch-Slack $\left(\mathrm{C}_{4}\right)$ carbon fixation

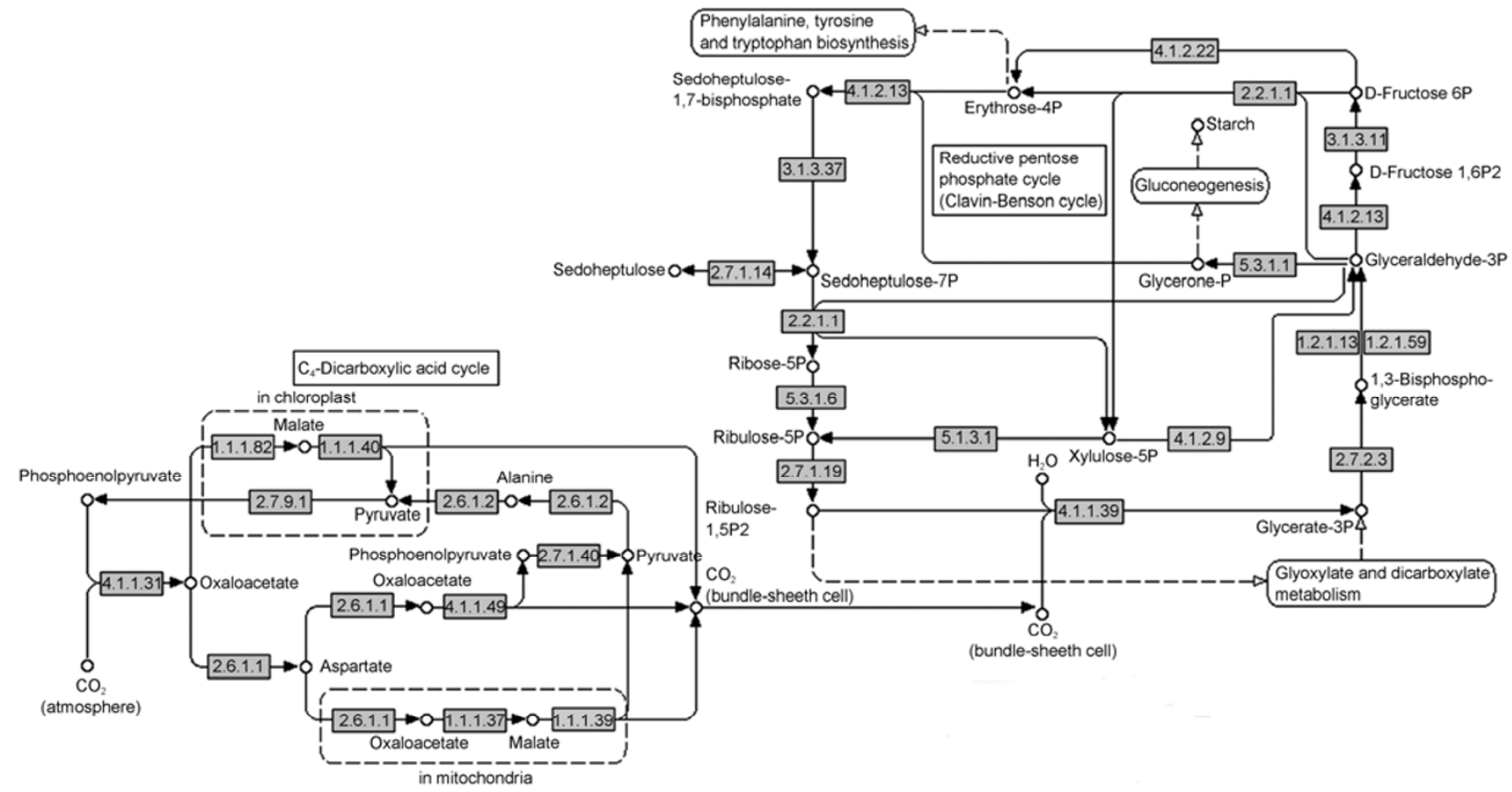

Figure 1 Carbon fixation pathway of $U$. linza from KEGG. EC numbers marked with light grey grounding indicate the key enzymes we got from transcriptome sequencing [28]. 
pathway in $U$. linza (Figure 1).

\subsection{Photosynthetic parameters}

The optimum quantum yield $\left(F_{\mathrm{v}} / F_{\mathrm{m}}\right)$ and effective PSII quantum yield $(Y($ II $)$ ) were measured to investigate the growth condition in $U$. linza subjected to different forms and intensities of stress. As shown in Figure $2 \mathrm{~A}, F_{\mathrm{v}} / F_{\mathrm{m}}$ and $Y$ (II) reduced under desiccation conditions, which indicated desiccation was stress condition for $U$. linza. For the salinity and temperature experiment, $F_{\mathrm{v}} / F_{\mathrm{m}}$ and $Y($ II) changed only slightly under high salinity, low salinity, high temperature and low temperature conditions (Figure 2B and D), which indicated that $U$. linza was not obviously stressed. Figure $2 \mathrm{C}$ shows $F_{\mathrm{v}} / F_{\mathrm{m}}$ and $Y($ II) decreased quickly under high light intensity, which demonstrated high light intensity was stress condition for $U$. linza.

\subsection{Analysis of $r b c \mathrm{~L}$ and $P P D K$ gene expression under various forms of stress}

Expression levels of $r b c \mathrm{~L}$ and $P P D K$ genes under the different stress treatments were determined by relative quantitative PCR. Figure $3 \mathrm{~A}$ and $\mathrm{B}$ shows the profile of expression of $r b c \mathrm{~L}$ and $P P D K$ as affected by desiccation for varying lengths of time. The expression levels of $r b c \mathrm{~L}$ and $P P D K$ under normal conditions were taken as 1 . The tran- script levels of $r b c \mathrm{~L}$ reduced slowly along with the time whereas $P P D K$ increased steadily at first, peaking (a 25.2-fold increase) at $4 \mathrm{~h}$, and decreased thereafter. Levels of salinity affected the expression markedly compared to that under normal salinity (30\%o), which was taken as 1 . The transcript levels of $r b c \mathrm{~L}$ decreased at both low and high levels of salinity, the highest expression being that at the normal level of $30 \%$, whereas those of PPDK exhibited the exact opposite, with higher levels at both low and high salinity (Figure 3C and D). Changes in expression levels under different light intensities are shown in Figure $3 \mathrm{E}$ and $\mathrm{F}$. For each gene, the expression under $50 \mu \mathrm{mol} \mathrm{m} \mathrm{m}^{-2} \mathrm{~s}^{-1}$ was taken as 1 . The expression level of $r b c \mathrm{~L}$ in the dark was similar to that under normal light intensity, whereas that of $P P D K$ was up-regulated 2-fold in the dark. Both peaked at $200 \mu \mathrm{mol} \mathrm{m} \mathrm{m}^{-2} \mathrm{~s}^{-1}$. Although the expression of PPDK decreased under high light intensity, it was still higher than that under normal light intensity. Moreover, the effect of light intensities on $P P D K$ was significantly higher than that on $r b c \mathrm{~L}$. The expression of $r b c \mathrm{~L}$ and $P P D K$ at normal temperature $\left(10^{\circ} \mathrm{C}\right)$ was taken as 1 , which happened to be the peak for both $r b c \mathrm{~L}$ and $P P D K$; the levels of both fell at temperatures higher or lower than normal (Figure 3G and $\mathrm{H}$ ) although $P P D K$ was affected more significantly at $0^{\circ} \mathrm{C}$ and $30^{\circ} \mathrm{C}$. In a word, the expression of $r b c \mathrm{~L}$ was higher under normal conditions and lower under the adverse conditions, whereas that of PPDK was higher under some adverse con-
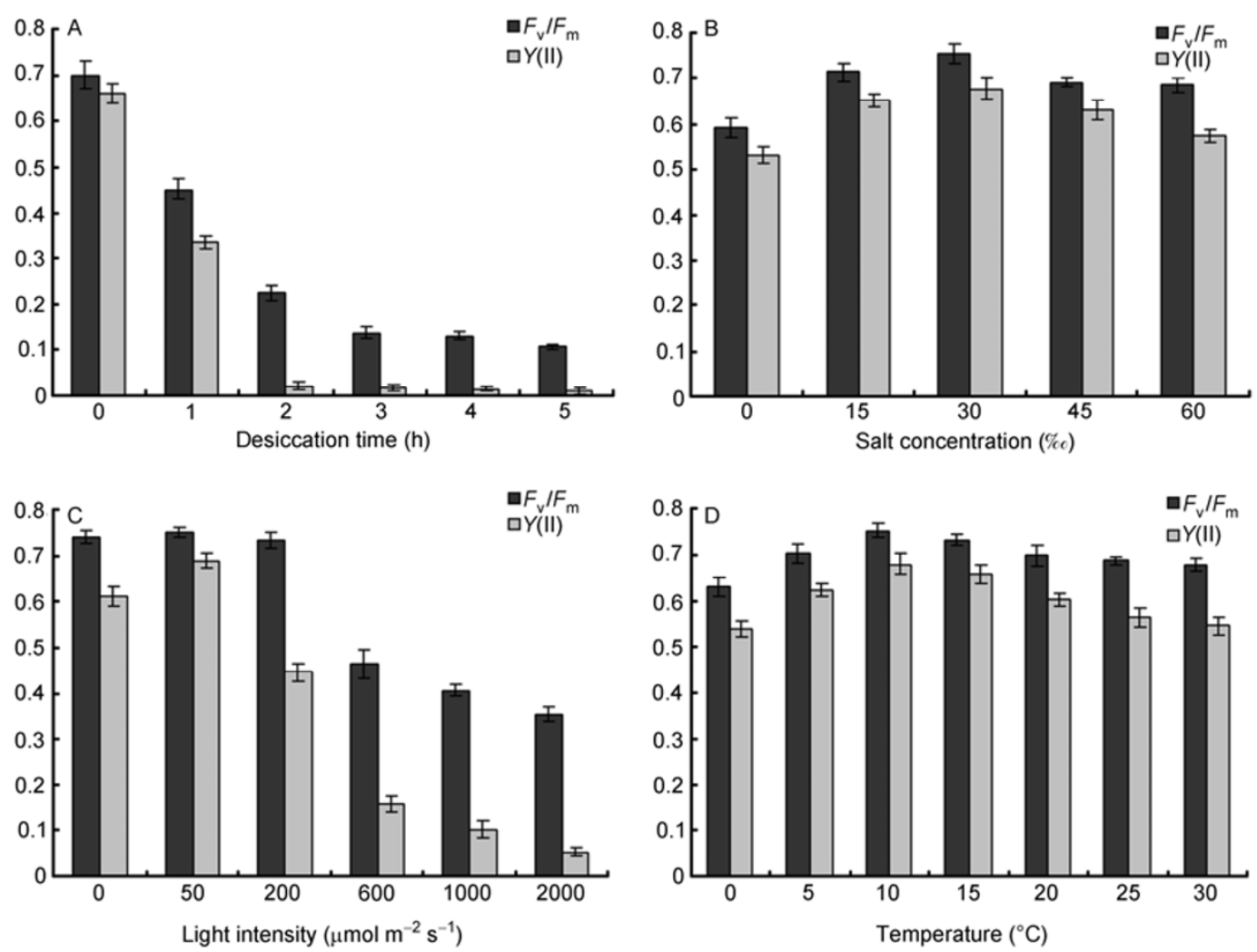

Figure 2 Optimum quantum yield $\left(F_{\mathrm{v}} / F_{\mathrm{m}}\right)$ and effective PS II quantum yield $(Y(\mathrm{II}))$ in $U$. linza under different forms and intensities of stress. A, Desiccation for different durations up to $5 \mathrm{~h}$. B, Different salt concentrations for $1 \mathrm{~h}$. C, Different light intensities for $1 \mathrm{~h}$. D, Different temperatures for $1 \mathrm{~h}$. 

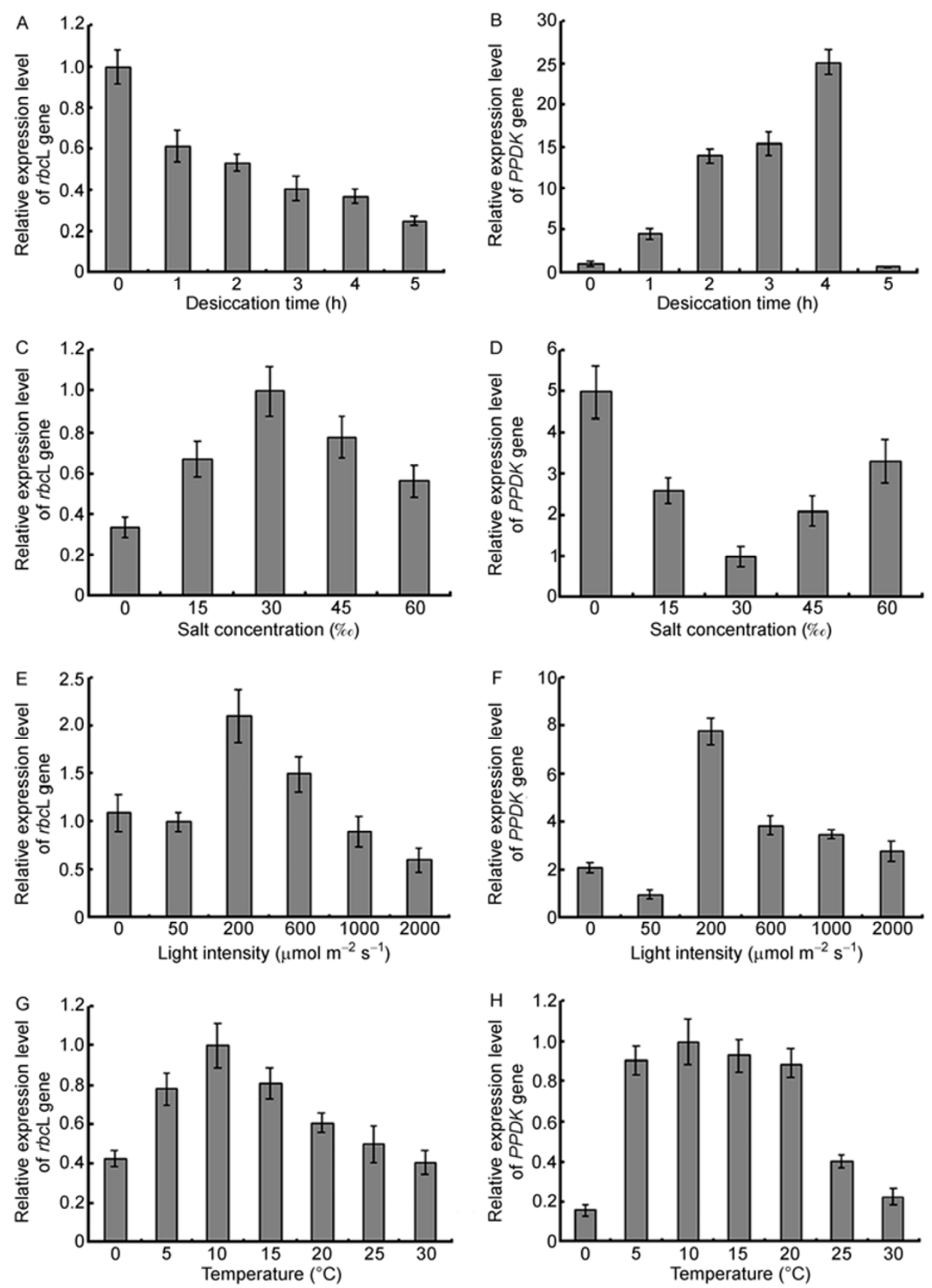

Figure 3 Real-time quantitative PCR analysis for the relative expression level of $r b c \mathrm{~L}$ and $P P D K$ gene in $U$. linza subjected to different forms and intensities of stress. Data are means of three independent experiments $( \pm \mathrm{SD})$. Relative mRNA expression of $r b c \mathrm{~L}$ and $P P D K$ exposed to different stress conditions. $\mathrm{A}$ and $\mathrm{B}$, Desiccation for different durations up to $5 \mathrm{~h}$. $\mathrm{C}$ and $\mathrm{D}$, Different salt concentrations for $1 \mathrm{~h}$. E and $\mathrm{F}$, Different light intensities for $1 \mathrm{~h}$. G and $\mathrm{H}$, Different temperatures for $1 \mathrm{~h}$.

ditions, namely desiccation, high salinity, and low salinity.

\subsection{Activity of RuBP carboxylase and PPDK}

The activity of RuBP carboxylase weakend significantly with the duration of desiccation, the lowest level being nearly $50 \%$ of the normal level, whereas that of PPDK im- proved with the duration up to $4 \mathrm{~h}$, the peak value being double the normal value, and decreased thereafter (Figure 4A). The activity of PPDK was very high under desiccation condition, even exceed RuBP carboxylase between 3-5 h. The effect of salinity level on RuBP carboxylase activity was the exact opposite of that on PPDK activity (Figure 4B): $30 \%$ salinity led to the highest level of RuBP carboxylase 

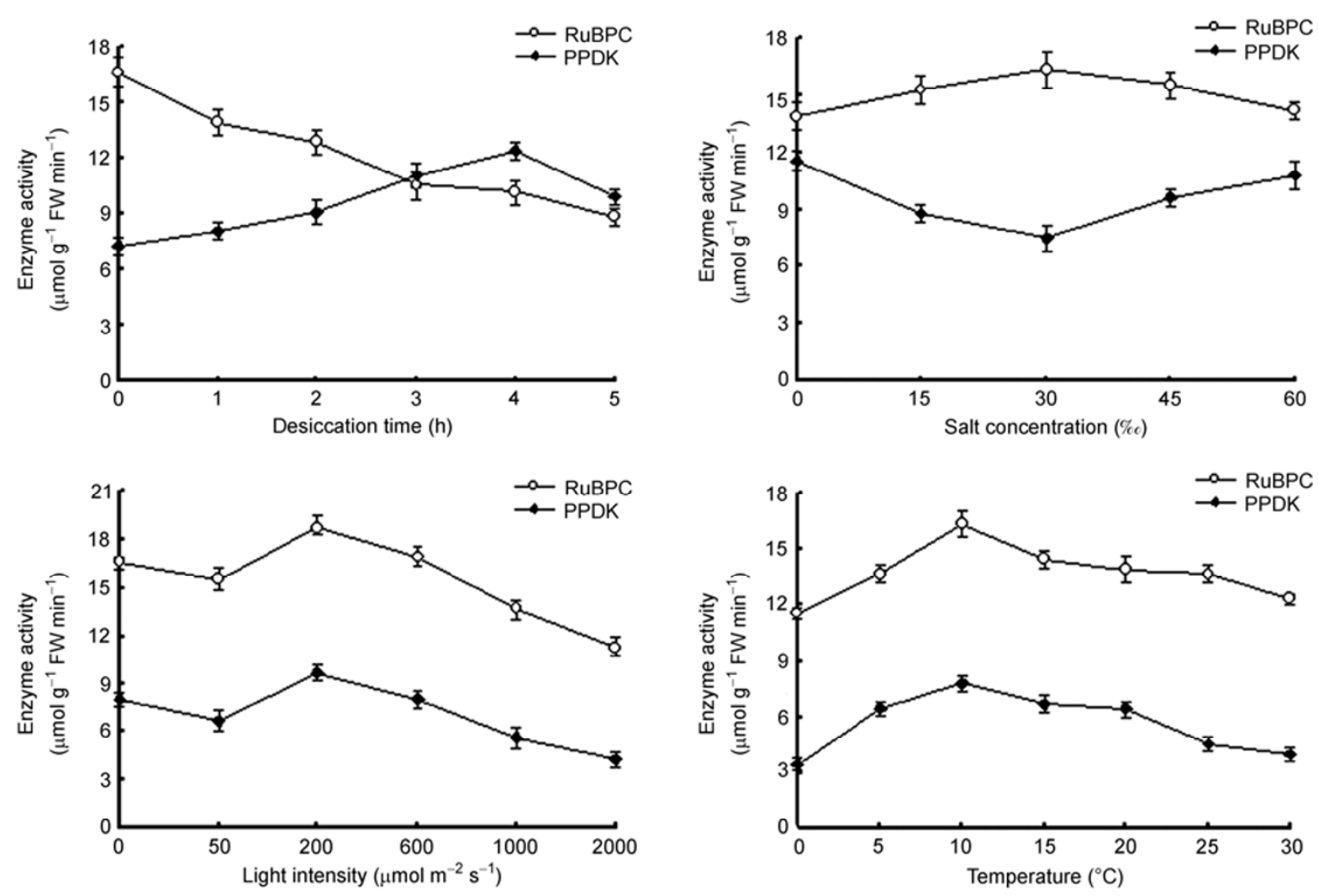

Figure 4 Activity of RuBP carboxylase and PPDK in $U$. linza exposed to different forms and intensities of stress. A, Desiccation for different durations up to $5 \mathrm{~h}$. B, Different salt concentrations for $1 \mathrm{~h}$. C, Different light intensities for $1 \mathrm{~h}$. D, Different temperatures for $1 \mathrm{~h}$.

activity and the lowest level of PPDK activity. Varying light intensities obviously influenced the activity of the two enzymes in a similar pattern: the activity began to rise initially, peaked at $200 \mu \mathrm{mol} \mathrm{m} \mathrm{m}^{-2} \mathrm{~s}^{-1}$, and then dropped with light intensity strengthened further (Figure 4C). Almost no change in the activity of RuBP carboxylase and PPDK between the level under normal light intensity and darkness. Temperature affected both RuBP carboxylase and PPDK activity significantly and similarly (Figure 4D): both recorded maximum activity at $10^{\circ} \mathrm{C}$, a level 1.4 -fold and 2.2-fold than the lowest temperatures respectively. In short, both ribulose-1, 5-biphosphate carboxylase (RuBPCase) and PPDK were found to play a role in carbon fixation, with significantly higher PPDK activity across some stress conditions.

\section{Discussion}

The $\mathrm{C}_{4}$ photosynthetic pathway is thought to be an exceptional evolutionary adaptation. Through a combination of structural and biochemical modifications brought about by mutation of genes encoding, for the most part, proteins in- volved in anaplerotic functions in ancestral $\mathrm{C}_{3}$ species, $\mathrm{C}_{4}$ plants gained the ability to outcompete these ancestors in arid, high light intensity, and saline environments that promote photorespiration [3]. $\mathrm{C}_{4}$ plants are believed to have evolved gradually from $\mathrm{C}_{3}$ plants through several intermediate stages of $\mathrm{C}_{3}-\mathrm{C}_{4}$ plants [35]. However, the evolutionary processes coming into being $\mathrm{C}_{3}-\mathrm{C}_{4}$ intermediates and $\mathrm{C}_{4}$ plants are yet to be elaborated. In the present study, $\mathrm{C}_{4}$ photosynthesis carbon fixation was found in the green-tideforming macroalga $U$. linza by means of transcriptomic analysis and molecular determination, pointing to the existence and functioning of $\mathrm{C}_{4}$ photosynthesis in $U$. linza. In addition, enzyme analysis indicated that PPDK was more important for plants under stress than for those growing under optimal growth conditions. These breakthroughs give new opportunities to further uncover the origins of the $\mathrm{C}_{4}$ pathway and its functions in $\mathrm{C}_{3}$ plants.

The expression levels of $P P D K$ were higher than $r b c \mathrm{~L}$ under some forms of stress. The transcript levels of $P P D K$ increased under desiccation condition, whereas those of $r b c \mathrm{~L}$ decreased. The activity of RuBP carboxylase and PPDK had similar tendency under desiccation condition, which indicated desiccation condition may induce the ex- 
pression of $\mathrm{C}_{4}$ photosynthesis and restrain the expression of $\mathrm{C}_{3}$ photosynthesis. The expression level of $P P D K$ rose at both low and high levels of salinity, whereas those of $r b c \mathrm{~L}$ exhibited the exact opposite. The activity of RuBP carboxylase and PPDK also had similar tendency at high and low salinity conditions, which indicated high and low salinity conditions may induce the expression of $\mathrm{C}_{4}$ photosynthesis and suppress the expression of $\mathrm{C}_{3}$ photosynthesis. The expression of $r b c \mathrm{~L}$ and $P P D K$ had similar tendency under different light intensity and temperature conditions, which demonstrated high light intensity and high temperature may not induce $\mathrm{C}_{4}$ photosynthesis in $U$. linza .

Recently, the $\mathrm{C}_{4}$ pathway has been researched at the systems level by contrasting the transcriptome of a $\mathrm{C}_{4}$ species to that of a closely related $\mathrm{C}_{3}$ species $[5,36]$. Multiple independent origins of $\mathrm{C}_{4}$ photosynthesis suggest that the evolution of a $\mathrm{C}_{3}$ into a $\mathrm{C}_{4}$ plants must have been relatively easy in genetic terms [37]. It is deduced that $\mathrm{C}_{4}$ plants evolved from their $\mathrm{C}_{3}$ ancestors at least 30 million years ago [38], and their expansion at the expense of $\mathrm{C}_{3}$ plants in the late Miocene led to large-scale and lasting changes in climate and in ecosystems, modifying the frequency of fires and influencing the distribution and evolution of $\mathrm{C}_{4}$ herbivores, including humans $[1,39,40]$. The $\mathrm{C}_{4}$ photosynthetic pathway is one of the most significant complex adaptive traits ever acquired by hydrophytes, and the notion that aquatic environment is relatively 'benign' for plants and lacks the selection pressure that resulted in terrestrial $\mathrm{C}_{4} \mathrm{CO}_{2}$-concentrating mechanism. Thus $\mathrm{C}_{4}$ systems in algae appear to be ancient forms of $\mathrm{C}_{4}$ photosynthesis that probably predate terrestrial $\mathrm{C}_{4}$ plants and appear to have originated in waters subjected to localized $\mathrm{CO}_{2}$ depletion [6].

Stress conditions often negatively affect key metabolic processes in plants [41]. However, enhanced activity of proteins related to the $\mathrm{C}_{4}$ pathway, including PPDK, was found in higher plants under various abiotic forms of stress, such as drought, ozone, high salinity, the presence of heavy metals in soil, and the absence of phosphate and iron [40]. Moreover, the activity of these enzymes was enhanced in plants under biotic forms of stress caused by viral infections [40]. The functions of the enzymes of $\mathrm{C}_{4}$ pathway appear to be more important for plants under stress conditions than for those under optimal growth conditions [42]. High temperature is a major environmental requirement for the evolution of $\mathrm{C}_{4}$ pathway because high temperature directly stimulates photorespiration and dark respiration in $\mathrm{C}_{3}$ plants $[43,44]$. The availability of $\mathrm{CO}_{2}$ as a substrate also declines at high temperatures because of lower solubility of $\mathrm{CO}_{2}$ relative to that of $\mathrm{O}_{2}$ [45]. Aridity and salinity are also significant environmental elements because they promote stomatal closure and reduce the concentration of intercellular $\mathrm{CO}_{2}$, which stimulate photorespiration and aggravate the deficiency of $\mathrm{CO}_{2}$ as a substrate [46-48]. Many $\mathrm{C}_{3}-\mathrm{C}_{4}$ in- termediates, such as intermediate species of Heliotropium [49], Salsola [50], Alternanthera [51], Neurachne [51], and a number of the Flaveria [52], are from arid or saline zones.

$\mathrm{C}_{4}$ photosynthesis in marine environments is particularly significant because it is likely to influence the sensitivity of algae to changes in $\mathrm{CO}_{2}$ concentrations [16]. If $\mathrm{C}_{4}$ photosynthesis can account for a significant portion of carbon fixation in some marine species, it will affect various aspects of marine ecology and biogeochemistry [16]. Ulva species are also highly tolerant of variations in salinity, temperature, and irradiance and are considered to be the main cause of green tides. The existence and rise of $\mathrm{C}_{4}$ photosynthesis expression level under some stress conditions in $U$. linza may account for the outbreaks of green tides and the high tolerance to various adverse environmental conditions shown by the species.

Although the exact mechanism of the uptake of inorganic carbon and its assimilation in marine green algae, particularly the relative importance of $\mathrm{C}_{4}$ and $\mathrm{C}_{3}$ photosynthesis under various conditions, need to be elucidated further, our results indicate that $\mathrm{C}_{4}$ pathway may play a significant role in carbon fixation. Short-term photosynthetic ${ }^{14} \mathrm{C}$ labeling can be used to explore $\mathrm{C}_{4}$ pathways in $U$. linza in greater detail. Intriguingly, the results point to the evolution of a photorespiratory $\mathrm{CO}_{2}$-concentrating pump prior to the establishment of the $\mathrm{C}_{4}$ pathway $\mathrm{CO}_{2}$-concentrating pump [40]. This comprehensive study adds to our knowledge of $\mathrm{C}_{4}$ evolution and provides adequate data to guide future work.

This work was supported by Shandong Science and Technology Plan Project (2011GHY11528), the Specialized Fund for the Basic Research Operating Expenses Program (20603022012004), National Natural Science Foundation of China (41176153), Natural Science Foundation of Shandong Province (2009ZRA02075), Qingdao Municipal Science and Technology Plan Project (11-3-1-5-hy), Qingdao Municipal Science and Technology Plan Project (10-3-4-11-1-jch), and National Marine Public Welfare Research Project (200805069).

1 Cerling T E, Wang Y, Quade J. Expansion of $\mathrm{C}_{4}$ ecosystems as an indicator of global ecological change in the late Miocene. Nature, 1993, 361: 344-345

2 Christin P A, Freckleton R P, Osborne C P. Can phylogenetics identify $\mathrm{C}_{4}$ origins and reversals? Trends Ecol Evol, 2010, 25: 403409

3 Ludwig M. Carbonic anhydrase and the molecular evolution of $\mathrm{C}_{4}$ photosynthesis. Plant Cell Environ, 2012, 35: 22-37

4 Whitney S M, Sharwood R E, Orr D, et al. Isoleucine 309 acts as a $\mathrm{C}_{4}$ catalytic switch that increases ribulose-1,5-bisphosphate carboxylase/oxygenase (rubisco) carboxylation rate in Flaveria. Proc Natl Acad Sci USA, 2011, 108: 14688-14693

5 Gowik U, Westhoff $\mathrm{P}$. The path from $\mathrm{C}_{3}$ to $\mathrm{C}_{4}$ photosynthesis. Plant Physiol, 2011, 155: 56-63

6 Bowes G. Single-cell $\mathrm{C}_{4}$ photosynthesis in aquatic plants. In: Raghavendra A S, Sage R F, eds. $\mathrm{C}_{4}$ Photosynthesis and Related $\mathrm{CO}_{2}$ Concentrating Mechanisms. Dordrecht: Springer Science+Business 
Media B.V., 2011. 63-80

7 Magnin N C, Cooley B C, Reiskind J B, et al. Regulation and localization of key enzymes during the induction of Kranz-less, $\mathrm{C}_{4}$-type photosynthesis in Hydrilla verticillata. Plant Physiol, 1997, 115: 1681-1689

8 Spencer W E, Teeri J, Wetzel R G. Acclimation of photosynthetic phenotype to environmental heterogeneity. Ecology, 1994, 75: 301-314

9 Rao S K, Fukayama H, Reiskind J B, et al. Identification of $\mathrm{C}_{4}$ responsive genes in the facultative $\mathrm{C}_{4}$ plant Hydrilla verticillata. Photosynth Res, 2006, 88: 173-183

10 Beer S, Israel A, Drechsler Z, et al. Photosynthesis in Ulva fasciata V. Evidence for an inorganic carbon concentrating system, and ribulose-1,5-bisphosphate carboxylase/oxygenase $\mathrm{CO}_{2}$ kinetics. Plant Physiol, 1990, 94: 1542-1546

11 Axelsson C, Larsson C, Ryberg H. Affinity, capacity and oxygen sensitivity of two different mechanisms for bicarbonate utilization in Ulva lactuca L. (Chlorophyta). Plant Cell Environ, 1999, 22: 969978

12 Giordano M, Beardall J, Raven J A. $\mathrm{CO}_{2}$ concentrating mechanisms in algae: mechanisms, environmental modulation, and evolution. Annu Rev Plant Biol, 2005, 56: 99-131

13 Reinfelder J R. Carbon concentrating mechanisms in eukaryotic marine phytoplankton. Annu Rev Mar Sci, 2011, 3: 291-315

14 Kremer B P. Aspects of carbon metabolism in marine macroalgae. Oceanogr Mar Biol Annu Rev, 1981, 19: 41-94

15 Reinfelder J R, Kraepiel A M I, Morel F M M. Unicellular $\mathrm{C}_{4}$ photosynthesis in a marine diatom. Nature, 2000, 407: 996-999

16 Reinfelder J R, Milligan A J, Morel F M M. The role of the $\mathrm{C}_{4}$ pathway in carbon accumulation and fixation in a marine diatom. Plant Physiol, 2004, 135: 2106-2111

17 Montsant A, Jabbari K, Maheswari U, et al. Comparative genomics of the pennate diatom Phaeodactylum tricornutum. Plant Physiol, 2005, 137: 500-513

18 Derelle E, Ferraz C, Rombauts S, et al. Genome analysis of the smallest free-living eukaryote Ostreococcus tauri unveils many unique features. Proc Natl Acad Sci USA, 2006, 103: 1164711652

19 McGinn R J, Morel F M M. Expression and Inhibition of the carboxylating and decarboxylating enzymes in the photosynthetic $\mathrm{C}_{4}$ pathway of marine diatoms. Plant Physiol, 2008, 146: 300-309

20 Beer S, Israel A. Photosynthesis of Ulva sp: III. $\mathrm{O}_{2}$ effects, carboxylase activities, and the $\mathrm{CO}_{2}$ incorporation pattern. Plant Physiol, 1986, 81: 937-938

21 Dong M, Zhang X, Zhuang Z, et al. Characterization of the LhcSR gene under light and temperature stress in the green alga Ulva linza. Plant Mol Biol Rep, 2011, doi: 10.1007/s11105-011-0311-8

22 Ye N, Zhang X, Mao Y, et al. 'Green tides' are overwhelming the coastline of our blue planet: taking the world's largest example. Ecol Res, 2011, 26: 477-485

23 Cohen R A, Fong P. Using opportunistic green macroalgae as indicators of nitrogen supply and sources to estuaries. Ecol Appl, 2006, 16: $1405-1420$

24 Conley D J, Paerl H W, Howarth R W, et al. Controlling eutrophication: nitrogen and phosphorus. Science, 2009, 323: 10141015

25 Aquino R S, Grativol C, Mourao P A S. Rising from the sea: correlations between sulfated polysaccharides and salinity in plants. PLoS ONE, 2011, 6: e18862

26 Hatch M D. $\mathrm{C}_{4}$ photosynthesis: a unique blend of modified biochemistry, anatomy and ultrastructure. Biochem Biophys Acta, 1987, 895: 81-106

27 Ishimaru K, Ohkawa Y, Ishige T, et al. Elevated pyruvate orthophosphate dikinase (PPDK) activity alters carbon metabolism in $\mathrm{C}_{3}$ transgenic potatoes with a $\mathrm{C}_{4}$ maize PPDK gene. Physiol Plantarum, 1998, 103: 340-346

28 Xu J, Fan X, Zhang X, et al. Evidence of coexistence of $\mathrm{C}_{3}$ and $\mathrm{C}_{4}$ photosynthetic pathways in a green-tide-forming alga, Ulva prolifera. PLoS ONE, 2012, 7: e37438

29 Huson D H, Auch A F, Qi J, et al. Megan analysis of metagenome data. Genome Res, 2007, 17: 377-386

30 Beer S, Larsson C, Poryan O, et al. Photosynthetic rates of Ulva (Chlorophyta) measured by pulse amplitude modulated (PAM) fluorometry. Eur J Phycol, 2000, 35: 69-74

31 Lin A P, Wang G C, Yang F, et al. Photosynthetic parameters of sexually different parts of Porphyra katadai var. hemiphylla (Bangiales, Rhodophyta) during dehydration and re-hydration. Planta, 2009, 229: 803-810

32 Dong $\mathrm{M} \mathrm{T}$, Zhang X W, Chi X Y, et al. The validity of a reference gene is highly dependent on the experimental conditions in green alga Ulva linza. Curr Genet, 2012, 58: 13-20

33 Gerard V A, Driscoll T. A spectrophotometric assay for RuBisCO activity: application to the kelp Laminaria saccharina and implications for radiometric assays. J Phycol, 1996, 32: 880-884

34 Sayre R T, Kennedy R A, Pringnitz D J. Photosynthetic enzyme activities and localization in Mollugo verticillata population differing on the leaves of $\mathrm{C}_{3}$ and $\mathrm{C}_{4}$ cycle operations. Plant Physiol, 1979, 64: 293-299

35 Ueno O. Structural and biochemical characterization of the $\mathrm{C}_{3}-\mathrm{C}_{4}$ intermediate Brassica gravinae and relatives, with particular reference to cellular distribution of Rubisco. J Exp Bot, 2011, 62: 53475355

36 Brautigam A, Kajala K, Wullenweber J, et al. An mRNA blueprint for $\mathrm{C}_{4}$ photosynthesis derived from comparative transcriptomics of closely related $\mathrm{C}_{3}$ and $\mathrm{C}_{4}$ species. Plant Physiol, 2011, 155: 142156

37 Westhoff P, Gowik U. Evolution of $\mathrm{C}_{4}$ photosynthesis-looking for the master switch. Plant Physiol, 2010, 154: 598-601

38 Edwards E J, Osborne C P, Strömberg C A E, et al. The origins of $\mathrm{C}_{4}$ grasslands: integrating evolutionary and ecosystem science. Science, 2010, 328: 587-591

39 Cowling S A, Jones C D, Cox P M. Consequences of the evolution of $\mathrm{C}_{4}$ photosynthesis for surface energy and water exchange. J Geophys Res, 2007, 112: G01020

40 Gowik U, Brautigam A, Weber K L, et al. Evolution of $\mathrm{C}_{4}$ photosynthesis in the genus Flaveria: How many and which genes does it take to make $\mathrm{C}_{4}$ ? Plant Cell, 2011, 23: 2087-2105

41 Moons R, Valcke R, Montagu M V. Low-oxygen stress and water deficit induce cytosolic pyruvate orthophosphate dikinase (PPDK) expression in roots of rice, a $\mathrm{C}_{3}$ plant. Plant J, 1998, 15: 8998

42 Doubnerova V, Ryslava $\mathrm{H}$. What can enzymes of $\mathrm{C}_{4}$ photosynthesis do for $\mathrm{C}_{3}$ plants under stress? Plant Sci, 2011, 180: 575-583

43 Brooks A, Farquhar G D. Effect of temperature on the $\mathrm{CO}_{2} / \mathrm{O}_{2}$ specificity of ribulose-1,5-bisphosphate carboxylase/oxygenase and the rate of respiration in the light. Planta, 1985, 165: 397406

44 Sharkey T D. Estimating the rate of photorespiration in leaves. Physiol Plantarum, 1988, 73: 147-152

45 Jordan D B, Ogren W L. The $\mathrm{CO}_{2} / \mathrm{O}_{2}$ specificity of ribulose 1,5-bisphosphate carboxylase/oxygenase. Planta, 1984, 161: 308313

46 Guy R D, Reid D M, Krouse H R. Shifts in carbon isotope ratios of two $C_{3}$ halophytes under natural and artificial conditions. Oecologia, 1980, 44: 241-247

47 Schulze E D, Hall A E. Stomatal responses, water loss and $\mathrm{CO}_{2}$ assimilation rates of plants in contrasting environments. In: Lange O L, Nobel P S, Osmond C B, et al., eds. Physiological Plant Ecology II: Water Relations and Carbon Assimilation. Berlin: Springer-Verlag, 1982. 181-230

48 Adam P. Saltmarsh Ecology. Cambridge: Cambridge University Press, 1990

49 Frohlich M W. Systematics of Heliotropium section Orthistachys in 
Mexico. Dissertation for Doctoral Degree. Boston: Harvard University, 1978

50 Voznesenskaya E V, Artyusheva E G, Franceschi V R, et al. Salsola arbusculiformis, a $\mathrm{C}_{3}-\mathrm{C}_{4}$ intermediate in Salsoleae (Chenopodiaceae). Ann Bot, 2001, 88: 337-348
51 Monson R K, Moore B D. On the significance of $\mathrm{C}_{3}-\mathrm{C}_{4}$ intermediate photosynthesis to the evolution of $\mathrm{C}_{4}$ photosynthesis. Plant Cell Environ, 1989, 12: 689-699

52 Powell A M. Systematics of Flaveria (Flaveriinae-Asteraceae). Ann Mo Bot Gard, 1978, 65: 590-636

Open Access This article is distributed under the terms of the Creative Commons Attribution License which permits any use, distribution, and reproduction in any medium, provided the original author(s) and source are credited. 